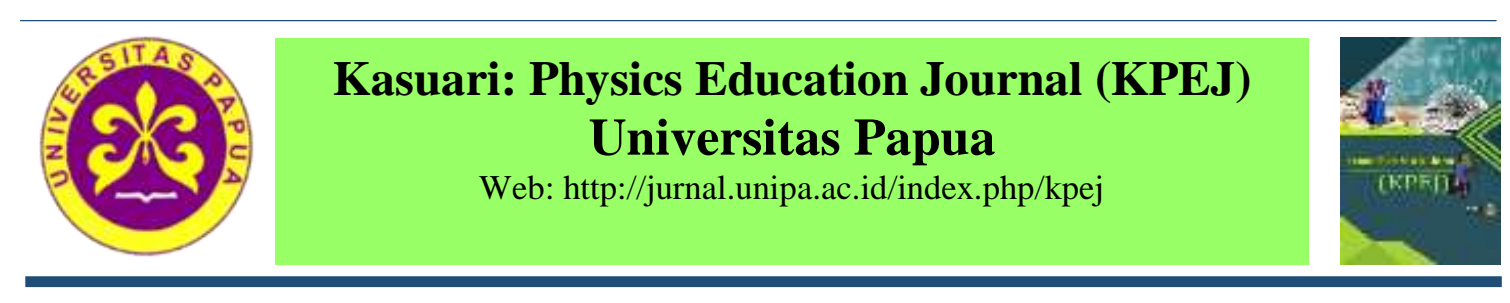

\title{
Application of Problem Posing Model for Achievement The Result of Physics Study at SMA Negeri 1 Taniwel
}

\author{
Amelia Niwele \& Beatus M. Laka* \\ Program Studi PGSD Sekolah Tinggi Keguruan dan Ilmu Pendidikan Biak \\ *Corresponding author: lakamendelson@gmail.com
}

\begin{abstract}
The purpose of this study was to determine the achievement of student learning outcomes using problem posing model in SMA Negeri I Taniwel. This type of research was descriptive. Random sampling technique was conducted to determine the sample of research that is class XI IPA I SMA Negeri I Taniwel. Technique of data analysis in the form of analysis of student achievement test result based on reference benchmark rating or reference standard. Formative test results (posttest) showed that most statements have achieved higher scores, after getting treatment through the problem posing model applied. The results showed that the problem posing model can help students in achieving good physics learning outcomes, especially on business and energy concepts with a final value of 82.6 .
\end{abstract}

Keywords: problem posing, learning outcomes

\section{Penerapan Model Problem Posing untuk Pencapaian Hasil Belajar Fisika di SMA Negeri 1 Taniwel}

\begin{abstract}
Abstrak: Tujuan penelitian ini yaitu untuk mengetahui pencapaian hasil belajar peserta didik menggunakan model problem posing di SMA Negeri I Taniwel. Jenis penelitian ini adalah deskriptif. Teknik random sampling dilakukan untuk menentukan sampel penelitian yaitu kelas XI IPA 1 SMA Negeri I Taniwel. Teknik analisis data berupa analisis hasil tes prestasi belajar peserta didik berdasarkan Penilaian Acuan Patokan (PAP) atau Standar Acuan Kriteria (SAK). Hasil tes formatif (post test) menunjukkan bahwa sebagian besar peserta didik telah mencapai skor yang lebih tinggi setelah pembelajaran melalui model problem posing. Hasil penelitian menunjukkan bahwa model problem posing dapat membantu peserta didik dalam mencapai hasil belajar fisika yang baik terutama pada konsep usaha dan energi dengan nilai akhir 82,6 .
\end{abstract}

Kata kunci: problem posing, hasil belajar

\section{PENDAHULUAN}

Dewasa ini peradaban manusia sangat diwarnai oleh tingkat penguasaan Ilmu Pengetahuan, Teknologi, dan Seni (IPTEKS). Fenomena ini mengakibatkan adanya persaingan dalam berbagai bidang kehidupan, salah satu diantaranya bidang pendidikan. Mutu pendidikan sangat diperlukan dalam mencetak sumber daya manusia yang berkualitas. Keberhasilan pendidikan tak terlepas dari peran sekolah. Pendidikan yang berlangsung di dalam lembaga pendidikan yang terarah mempunyai tujuan tertentu, agar mencapai tujuan dari pendidikan itu, maka diperlukan kurikulum sebagai sarana yang dapat menunjang semua kegiatan kependidikan kepada tujuan yang dikehendaki. Fisika merupakan salah satu cabang IPA yang mendasari perkembangan teknologi maju dan konsep hidup harmonis dengan alam. Perkembangan pesat di bidang teknologi informasi dan komunikasi dewasa ini dipicu oleh temuan di bidang fisika material (material sciene) melalui penemuan piranti mikroelektronika yang mampu membuat banyak informasi 
dengan ukuran sangat kecil (Wakhidah, 2007). Agar dapat menciptakan teknologi baru yang kreatif, inovatif sesuai dengan perkembangan IPTEKS serta mempersiapkan sumber daya manusia yang berdaya saing dalam mengatasi persoalan kehidupan, untuk itu peranan ilmu fisika sangat penting untuk mendukung hal tersebut. Olehnya itu penguasaan ilmu fisika sangat penting dalam kehidupan manusia (Rahmad, dkk., 2009: 34).

Sains pada dasarnya mencari hubungan kausal antara gejala-gejala alam yang diamati. Olehnya itu, proses pembelajaran sains harusnya mengembangkan kemampuan bernalar dan berfikir sistematis, selain kemampuan deklaratif yang telah dikembangkan sebagai inovasi untuk mencari model-model pembelajaran dalam pelajaran fisika sains. Belajar sains merupakan fokus kegiatan pada penemuan fenomena baru, pengolahan data yang menjadi temuan, kemudian memecahkan masalah berupa, mengukur, mengajukan pertanyaan, mengklasifikasi dan sebagainya (Wenno, 2011: 4).

Dikaitkan dengan pengertian fisika sebagai bagian dari sains, model pembelajaran yang melibatkan keaktifan peserta didik perlu diterapkan (Suliyati, dkk., 2018). Salah satu model pembelajaran yang menekankan pada keaktifan peserta didik dalam proses belajar yaitu model problem posing. Model problem posing secara langsung melibatkan aktivitas peserta didik dalam proses belajar, agar mereka dapat merumuskan dan menyelesaikan permasalahan yang dihadapi. Menurut Irawati (2014) problem posing dapat mengubah cara berpikir peserta didik, meningkatkan rasa percaya diri serta membantu memahami konsep dengan baik.

Alasan penulis memilih SMA Negeri I Taniwel sebagai tempat penelitian sebagai berikut: 1) ingin mengetahui hasil belajar peserta didik dengan menggunakan model problem posing dan 2) pada sekolah ini model problem posing belum diimplementasikan. Konsep usaha dan energi dipilih pada penelitian ini karena penulis ingin mengetahui sejauh mana kemampuan peserta didik dalam mendalami konsep usaha dan energi dengan menggunakan model problem posing dan karena konsep usaha dan energi ini juga sering ditemui dan dialami dalam kehidupan sehari-hari namun peserta didik belum mampu untuk memahaminya dengan baik. Tujuan penelitian ini yaitu untuk mengetahui pencapaian hasil belajar peserta didik kelas XI SMA Negeri I Taniwel menggunakan model problem posing pada konsep usaha dan energi.

\section{LANDASANTEORI}

\section{Hasil belajar}

Menurut Ratumanan (2002: 20) mengemukakan bahwa istilah hasil belajar identik dengan perolehan belajar yang mengacu pada penguasaan peserta didik terhadap tujuan pembelajaran yang ditetapkan. Hasil belajar atau scholastic achievement (academic achievement) adalah keseluruhan kecakapan dan hasil yang dicapai melalui proses belajar mengajar di sekolah yang dinyatakan dengan angka-angka atau nilai yang diukur dengan Tes Hasil Belajar (THB). Dalam buku Taksonomi of Educational Objektive, Bloom mendefenisikan hasil belajar sebagai hasil perubahan tingkah laku yang meliputi tiga ranah yakni: ranah kognitif, ranah afektif, dan ranah psikomotor (Wenno, 2011: 154). Kognitif berkaitan dengan perkembangan berpikir peserta didik mulai dari otak dan ini merupakan aspek utama dalam kurikulum pendidikan karena berkaitan dengan tolak ukur perkembangan belajar dan kemampuan mengembangkan pola berpikir peserta didik sampai pada penilaian. Ranah afektif berkenan dengan sikap dan nilai. Ranah afektif meliputi nilai, sikap atau tingkah laku seperti perasaan, minat sikap, dan emosi. Ranah psikomotor meliputi keterampilan, menciptakan benda-benda yang berhubungan dengan mengamati, serta menghubungkan benda-benda menjadi satu karya yang baik. Secara umum hasil belajar merupakan penilaian akhir dari awal proses dan pengalaman yang telah 
dilakukan berulang-ulang, dan tersimpan untuk jangka waktu lama atau bahkan tidak akan hilang begitunya sebab hasil belajar ikut membentuk pribadi yang selalu ingin mencapai hasil akhir yang lebih baik lagi sehingga akan merubah pola berfikir untuk menghasilkan perilaku kerja yang lebih baik.

\section{Model Problem Posing}

Problem posing merupakan istilah dalam bahasa Inggris yang berasal dari dua kata yaitu problem yang artinya masalah atau soal, dan posing dari kata to pose yang berarti mengajukan atau membentuk, sebagai pandanan istilah dalam bahasa Indonesia "pembentukan soal" atau "pengajuan soal" (problem posing) mempunyai beberapa arti. Problem posing merupakan istilah dalam bahasa Inggris, sebagai padanan katanya digunakan istilah merumuskan masalah (soal) atau membuat masalah atau soal (Rahmad, dkk., 2009: 35). Problem posing memiliki arti bahwa perumusan masalah yaitu peserta didik diarahkan untuk membuat soalnya sendiri. Hal ini digunakan untuk melatih peserta didik dalam berpikir kreatif dan juga memikirkan cara tepat untuk mengerjakan soal yang mereka buat tersebut. Sistem problem posing dikembangkan dengan empat fase yaitu perumusan masalah, perencanaan, penyelesaian masalah, dan refleksi, dimana fase pemecahan masalah diimplementasikan oleh skenario-permainan. (Chang, dkk., 2012).

Problem posing yang dilakukan peserta didik berisi tentang merumuskan soal setelah latihan oleh peserta didik yang ditugaskan guru kepada peserta didik untuk membuat soal dari situasi atau informasi yang dilakukan. Apabila peserta didik dapat menyelesaikan soal secara baik dari guru, dengan demikian guru memberikan kesempatan bagi peserta didik untuk menyampaikan pertanyaan lain yang sama tetapi dengan syarat yang berbeda. Perumusan soal yang dilakukan sebelum, ketika atau sesudah peserta didik memecahkan soal atau fenomena agar memunculkan pertanyaan yang baru dengan memodifikasi sendiri oleh peserta didik. Berkaitan dengan pemecahan soal, bahwa soal dapat dibentuk melalui adanya soal-soal yang ada di buku teks atau pelajaran, informasi tertulis atau gambar. Orientasi aktivitas peserta didik dalam pembelajaran melalui problem posing dapat melatih mereka untuk terampil dalam menyelesaikan berbagai permasalahan. Penerapan pembelajaran problem posing dapat mengembangkan kemampuan peserta didik dalam menyelesaikan permasalahan (Cankoy \& Darbaz, 2010).

\section{METODE PENELITIAN}

Jenis penelitian ini adalah penelitian deskriptif dengan pre-test dan post-test desain (Arikunto, 2012). Penelitian ini menggambarkan hasil belajar peserta didik dengan menggunakan model problem posing di kelas. Penelitian ini bertempat di SMA Negeri 1 Taniwel. Teknik random sampling dilakukan untuk menentukan sampel penelitian yaitu kelas XII IPA 1 yang berjumlah (20) peserta didik. Instrumen yang digunakan berupa instrument tes hasil belajar dan instrumen non-tes berupa lembar observasi dan Lembar Kerja Peserta Didik (LKPD). Penulis menggunakan sistem Penilaian Acuan Patokan (PAP) atau Standar Acuan Kriteria (SAK). Penilaian dilakukan yaitu pada saat KBM berlangsung ditambah dengan hasil terakhir. Teknik analisis yang dipakai untuk mengolah data penelitian ini yaitu analisis secara deskriptif kuantitatif. Skor pencapaian dari hasil tes awal dan tes akhir serta penilaian LKPD diperoleh melalui persamaan (1).

$$
\text { Skor Pencapaian }=\frac{\sum \text { SkorPerolehan }}{\sum \text { SkorTotal }} \times 100
$$

Nilai akhir yang menggambarkan tingkat penguasaan individu terhadap indikator kompetensi dari segi hasil maupun proses dikualifikasikan berdasarkan Tabel. 1. 
Tabel 1. Tingkat penguasaan kompetensi dan kualifikasi

\begin{tabular}{|c|c|c|}
\hline No & Tingkat Penguasaan Kompetensi & Kualifikasi \\
\hline 1 & $85-100$ & Sangat baik \\
\hline 2 & $75-84$ & Baik \\
\hline 3 & $65-74$ & Cukup \\
\hline 4 & $<65$ & Gagal \\
\hline
\end{tabular}

Sumber: Riduwan (2011).

\section{HASIL DAN PEMBAHASAN}

Hasil tes awal peserta didik menggambarkan kemampuan awal peserta didik sebelum mengikuti kegiatan belajar mengajar (KBM) materi usaha dan energi. Pencapaian peserta didik pada tes awal terdapat pada Tabel 2.

Tabel 2. Kualifikasi persentase (\%) pencapaian peserta didik pada tes awal

\begin{tabular}{|c|c|c|c|}
\hline Interval & Frekuensi & Persentase Pencapaian (\%) & Kualifikasi \\
\hline $85-100$ & - & - & Sangat baik \\
\hline $75-84$ & - & - & Baik \\
\hline $65-74$ & - & - & Cukup \\
\hline$<65$ & 20 & 100 & Gagal \\
\hline
\end{tabular}

Tabel 2 menunjukan bahwa kemampuan awal peserta didik mengenai materi usaha dan energi sebelum menerapkan model problem posing masih sangat rendah. Hal ini ditunjukkan dengan 20 peserta didik $(100 \%)$ dinyatakan gagal dan belum mampu menguasai indikator-indikator pembelajaran yang akan dipelajari. Dapat dikatakan ketuntasan belajar klasikal maupun individual belum tercapai dengan rata-rata nilai pencapaian adalah 40,4 .

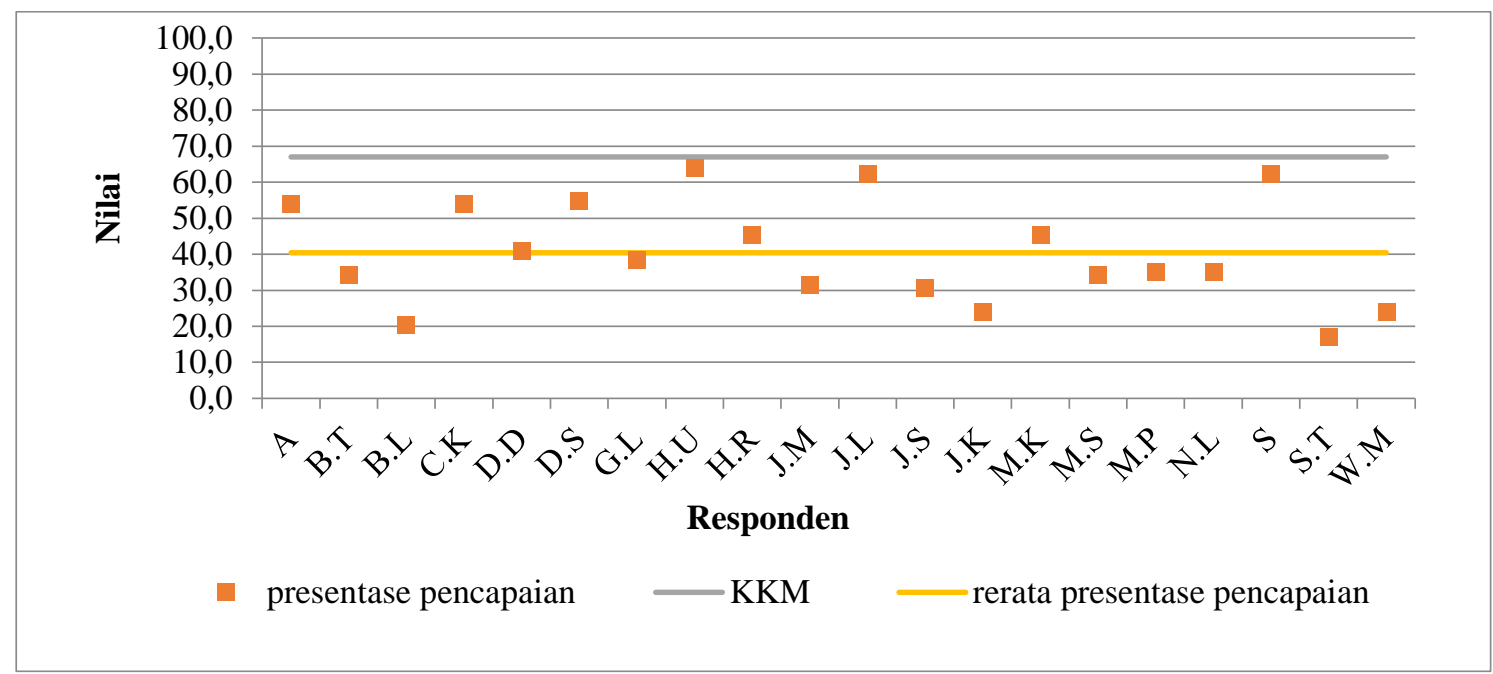

Gambar 1. Hasil tes awal peserta didik

Gambar 1 memperlihatkan bahwa semua peserta didik berada pada kualifikasi gagal (100\%), namun dari semua soal yang diberikan pada tes awal masih ada soal yang sudah bisa dikerjakan oleh peserta didik dengan benar, tapi hanya sebagian kecil dari soal yang diberikan yang mampu dikerjakan dengan benar oleh peserta didik. Ini berarti semua 
peserta didik masih memiliki kemampuan awal yang sangat rendah mengenai materi usaha dan energi sehingga semua indikator yang dikembangkan pada materi ini perlu diajarkan.

Selama penerapan pembelajaran problem posing, aspek kognitif dinilai melalui LKPD dan skor pencapaian hasil kemampuan kognitif sebagaimana pada Tabel 3. Terlihat bahwa seluruh peserta didik sebanyak 20 peserta didik (100\%) secara individual maupun klasikal dikatakan berhasil.

Tabel 3 Kualifikasi persentase pencapaian peserta didik pada aspek kognitif

\begin{tabular}{|c|c|c|c|}
\hline Interval & Frekuensi & Persentase Pencapaian $(\%)$ & Kualifikasi \\
\hline $85-100$ & 11 & 55 & Sangat baik \\
\hline $75-84$ & 9 & 45 & Baik \\
\hline $65-74$ & & & Cukup \\
\hline$<65$ & & & Gagal \\
\hline
\end{tabular}

Tabel 3 menunjukkan hasil pencapaian ranah kognitif yang diperoleh selama proses pembelajaran yang ditunjukan pada nilai LKPD terlihat bahwa sebanyak 11 (55\%) peserta didik mampu menyelesaikan LKPD dengan kualifikasi sangat baik, 9 peserta didik (45\%) mampu menyelesaikan LKPD dengan kualifikasi baik, Jika dibandingkan antara nilai KKM dengan rata-rata skor pencapaian peserta didik pada aspek kognitif, maka dapat dikatakan pencapaian kemampuan kognitif peserta didik berada pada kategori sangat baik, dengan rata-rata nilai pencapaian pada aspek kognitif adalah 87,9.

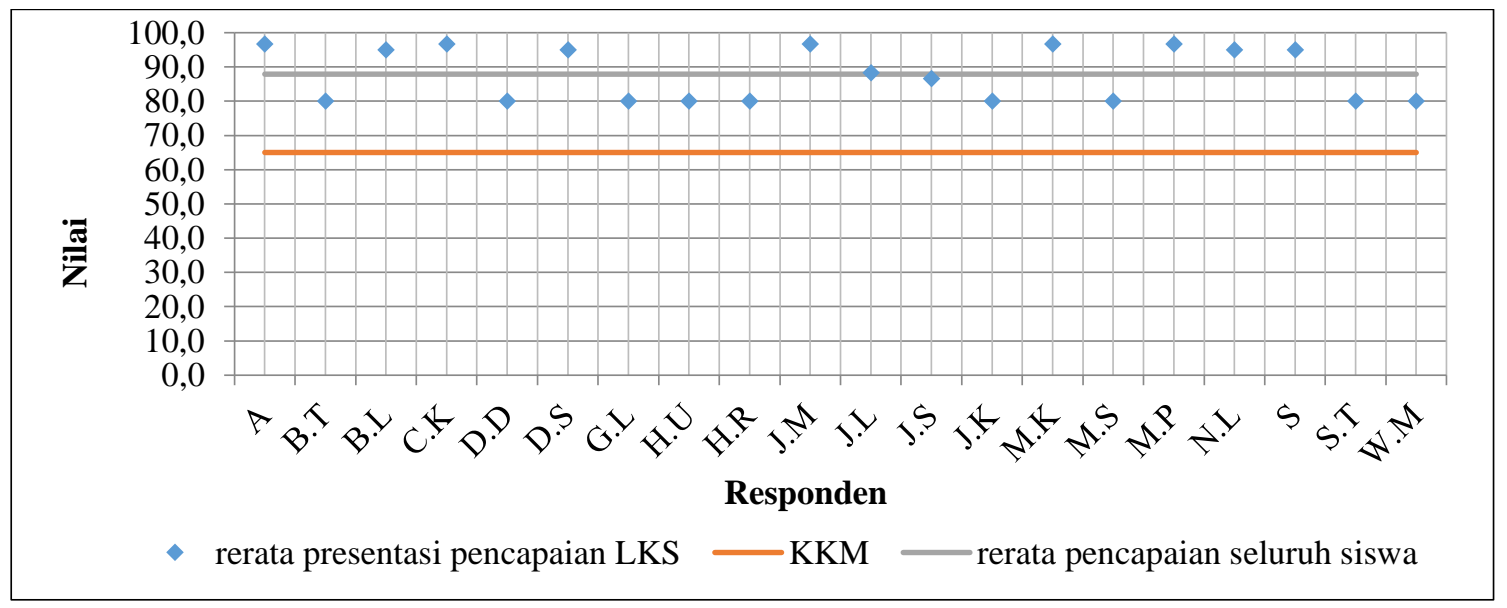

Gambar 2. Kemampuan kognitif peserta didik

Penilaian selama proses pembelajaran berlangsung selama 2 kali pertemuan Selama penerapan model problem posing, guru memberikan penilaian yang berhubungan dengan keadaan peserta didik selama proses belajar mengajar meliputi aspek kognitif, aspek afektif dan aspek psikomotor. Keberhasilan pada aspek kognitif dilihat melalui pengerjaan LKPD yaitu seluruh peserta didik dapat menyelesaikannya. Pembelajaran problem posing melibatkan peserta didik secara maksimal, untuk mencari, menyelidiki, membuat soal dan menyelsaikannya sendiri, secara sistematis seperti tertera pada langkah-langkah dalam LKPD. LKPD yang dirancang dengan melibatkan aktivitas peserta didik sangat berperan dalam meningkatkan hasil belajar mereka (Nurliawaty, dkk., 2017). Peserta didik bekerja berdasarkan urutan LKPD mulai dari membuat resume, membentuk soal, dan menyelesaikan masalah itu sampai merumuskan kesimpulan. Semua langkah dalam LKPD ini dapat dikerjakan secara baik oleh peserta didik karena mereka dapat berfikir secara 
kritis, logis, dan analitis untuk mengerjakannya. Peserta didik diberi kesempatan untuk mengembangkan kemampuannya sendiri dan saling membantu dalam kelompok mereka masing-masing serta erusaha sendiri untuk mencari, memecahankan masalah dan pengetahuan yang menyertainya, menghasilkan pengetahuan yang benar-benar bermakna (Trianto, 2007: 38). Sejalan dengan itu pendapat Sari, dkk (2017: 110) aktivitas peserta didik selama proses pembelajaran problem posing berlangsung dengan baik, meliputi menjadi pendengar yang baik, bertanya, memberikan pendapat, dan saling bekerja sama antar anggota kelompok. Pembelajaran problem posing dapat meningkatkan kemampuan kognitif peserta didik dalam belajar (Zakaria \& Ngah, 2011).

Data mengenai kemampuan afektif peserta didik diperoleh selama proses pembelajaran dengan menerapkan model problem posing ditunjukan pada nilai unjuk kerja peserta didik selama proses pembelajaran dengan kualifikasi sebagaimana pada Tabel 4.

Tabel 4. Kualifikasi persentase pencapaian peserta didik pada aspek afektif

\begin{tabular}{|c|c|c|c|}
\hline Interval & Frekuensi & Persentase Pencapaian (\%) & Kualifikasi \\
\hline $85-100$ & 8 & 40 & Sangat baik \\
\hline $75-84$ & 8 & 40 & Baik \\
\hline $65-74$ & 4 & 20 & Cukup \\
\hline$<65$ & & & Gagal \\
\hline
\end{tabular}

Tabel 4 menunjukkan bahwa hasil pencapaian peserta didik pada ranah afektif diperoleh bahwa 8 (40\%) peserta didik menempati kualifikasi sangat baik, 8 (40\%) peserta didik menempati kualifikasi baik, sedangkan $4(20 \%)$ peserta didik menempati kualifikasi cukup dan tidak ada peserta didik yang menempati kualifikasi gagal. Jika dibandingkan antara nilai KKM dengan rata-rata skor kemampuan peserta didik pada aspek afektif, maka dapat dikatakan pencapaian kemampuan afektif peserta didik memiliki kategori baik dengan rata-rata nilai pencapaian adalah 85,6.

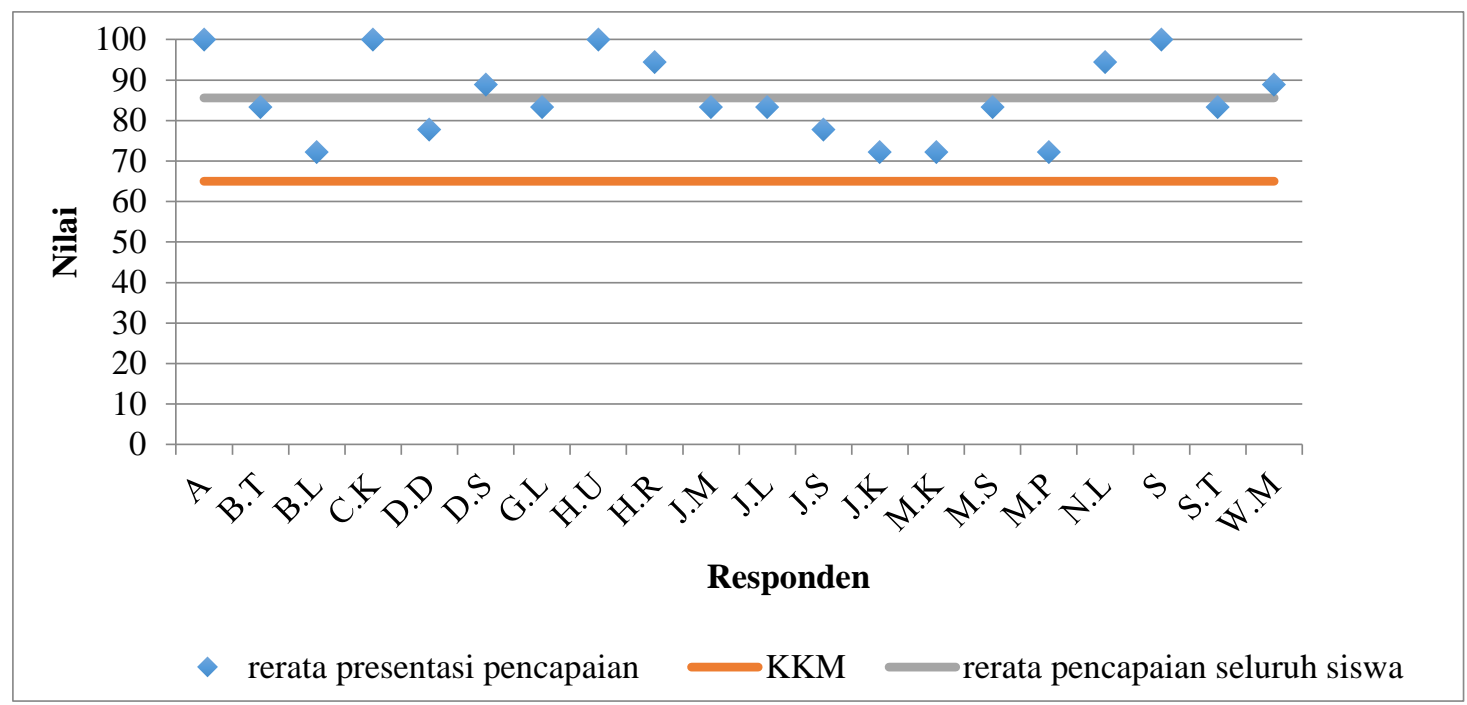

Gambar 3. Kemampuan afektif peserta didik

Gambar 3 memperlihatkan bahwa seluruh peserta didik (100\%) secara individual maupun klasikal telah berhasil. Hal ini disebabkan karena dari segi ranah afektif seperti kerja sama dalam kelompok terjalin dengan baik. Sikap kerja sama dan saling membantu ini, memberi peluang antara peserta didik untuk saling bertanya, dan keterbukaan untuk 
saling menerima usul atau saran atau pendapat teman. Semua komponen-komponen penilaian afektif ini dapat terbentuk dengan mudah karena skema peserta didik tentang materi usaha dan energi telah terbentuk dalam struktur kognitif peserta didik. Skema ini terbentuk setelah proses pembelajaran berlangsung dengan menerapkan model problem posing. Skema ini dapat digunakan untuk mengerti, menemukan jalan keluar, atau memecahkan persoalan baru. Seperti pendapat yang dikemukakan oleh Hatmawati, dkk (2016: 28) bahwa melalui pembelajaran problem posing, hasil belajar ranah afektif dan psikomotorik juga berhasil mencapai indikator keberhasilan yaitu berada pada kategori baik dan sangat terampil. Peningkatan hasil belajar tersebut tidak terlepas dari strategi yang telah diterapkan peneliti dalam perbaikan kegiatan pembelajaran. Pembelajaran problem posing berpengaruh positif terdapat aspek afektif peserta didik yaitu mereka menunjukkan sikap dan penilaian yang baik terhadap pembelajaran yang dilakukan (Akay \& Boz, 2010).

Kemampuan psikomotorik juga dapat dikembangkan melalui pembelajaran problem posing. Kemampuan psikomotor peserta didik yang diperoleh selama proses pembelajaran dengan menerapkan model problem posing sebagaimana pada tabel 3.

Tabel 5. Kualifikasi persentase pencapaian peserta didik pada aspek psikomotor

\begin{tabular}{|c|c|c|c|}
\hline Interval & Frekuensi & Persentase Pencapaian (\%) & Kualifikasi \\
\hline $85-100$ & 12 & 60 & Sangat baik \\
\hline $75-84$ & 5 & 25 & Baik \\
\hline $65-74$ & 3 & 15 & Cukup \\
\hline$<65$ & & & Gagal \\
\hline
\end{tabular}

Tabel 5 menunjukkan bahwa $12(60 \%)$ peserta didik termasuk kualifikasi sangat baik, $5(25 \%)$ peserta didik termasuk kualifikasi baik sedangkan $7(15 \%)$ peserta didik termasuk kualifikasi cukup dan tidak ada peserta didik yang menempati kualifikasi gagal. Jika dibandingkan antara nilai KKM dengan rata-rata skor pencapaiann peserta didik pada aspek psikomotor, maka dapat dikatakan pencapaian kemampuan psikomotor peserta didik memiliki kategori sangat baik nilai rata-rata pencapaian adalah 85,8 .

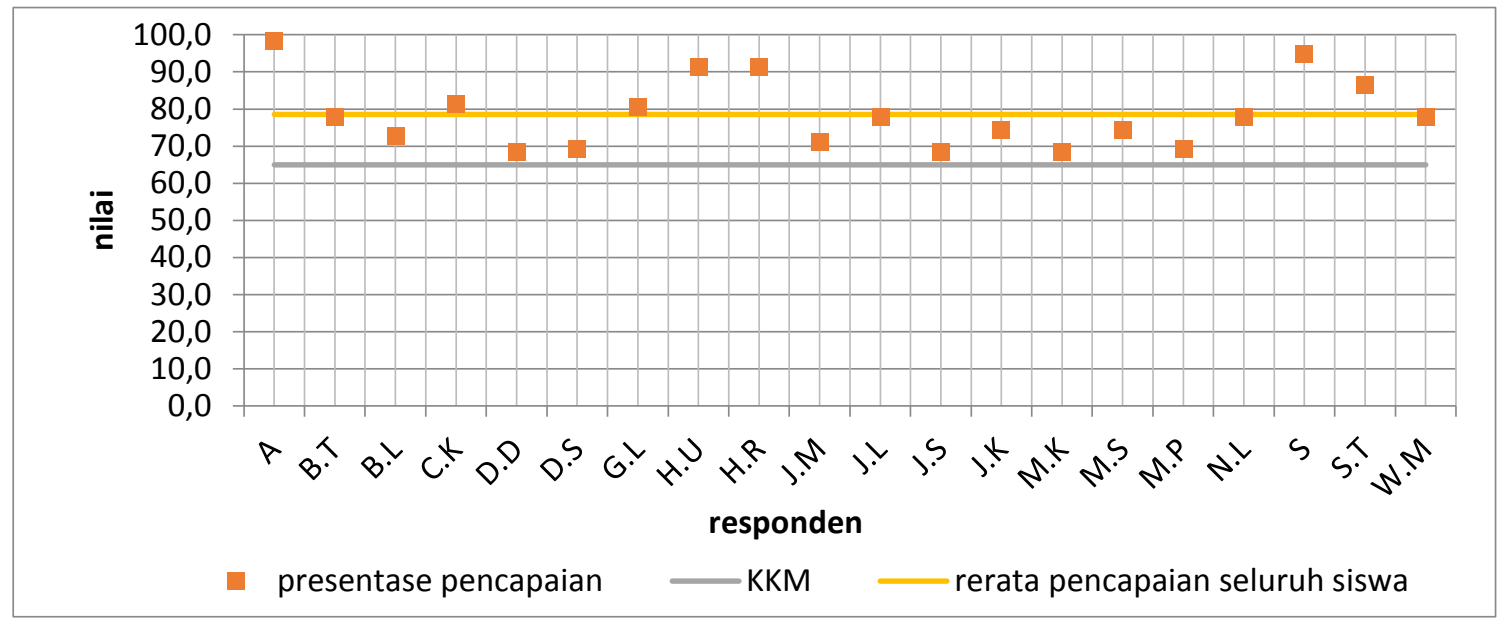

Gambar 4. Kemampuan psikomotor peserta didik

Penilaian mengenai aspek psikomotor peserta didik yang berhubungan dengan keterampilan tergambar pada Gambar 4. Gambar 4 menunjukkan bahwa seluruh peserta didik (100\%) juga baik secara individual maupun klasikal. Perkembangan aspek 
psikomotor ini disebabkan karena peserta didik telah menerima pengalaman belajar tertentu melalui proses penyampaian pertanyaan atau ide, menjawab pertanyaan dan membuat kesimpulan. Berdasarkan hasil yang diperoleh terlihat bahwa peserta didik ikut serta atau terlibat dalam menyampaikan pertanyaan, dan mencari informasi untuk menjawab pertanyaan sehingga pembelajaran model problem posing memiliki kategori baik bagi peserta didik untuk membangun keterampilan-keterampilan intelektual terkait dengan proses-proses berfikir mereka.

Kualifikasi persentase pencapaian peserta didik pada tes formatif yang dilakukan setelah kegiatan belajar mengajar dengan menerapkan model problem posing dapat dilihat pada Tabel 6.

Tabel 6. Kualifikasi persentase pencapaian peserta didik pada tes formatif

\begin{tabular}{|c|c|c|c|}
\hline Interval & Frekuensi & Persentase Pencapaian (\%) & Kualifikasi \\
\hline $85-100$ & 5 & 25 & Sangat baik \\
\hline $75-84$ & 6 & 30 & Baik \\
\hline $65-74$ & 9 & 45 & Cukup \\
\hline$<65$ & & & Gagal \\
\hline
\end{tabular}

Tabel 6 menunjukkan bahwa 5 (25\%) peserta didik menempati kualifikasi sangat baik, $6(30 \%)$ peserta didik menempati kualifikasi baik sedangkan $9(45 \%)$ peserta didik menempati kualifikasi cukup dan tidak ada peserta didik yang menempati kualifikasi gagal. Jika dibandingkan antara nilai KKM dengan rata-rata skor pencapaian peserta didik pada tes formatif, maka dapat dikatakan pencapaian kemampuan peserta didik berada pada kategori baik dengan rata-rata nilai pencapaian pada tes formatif adalah 78,5.

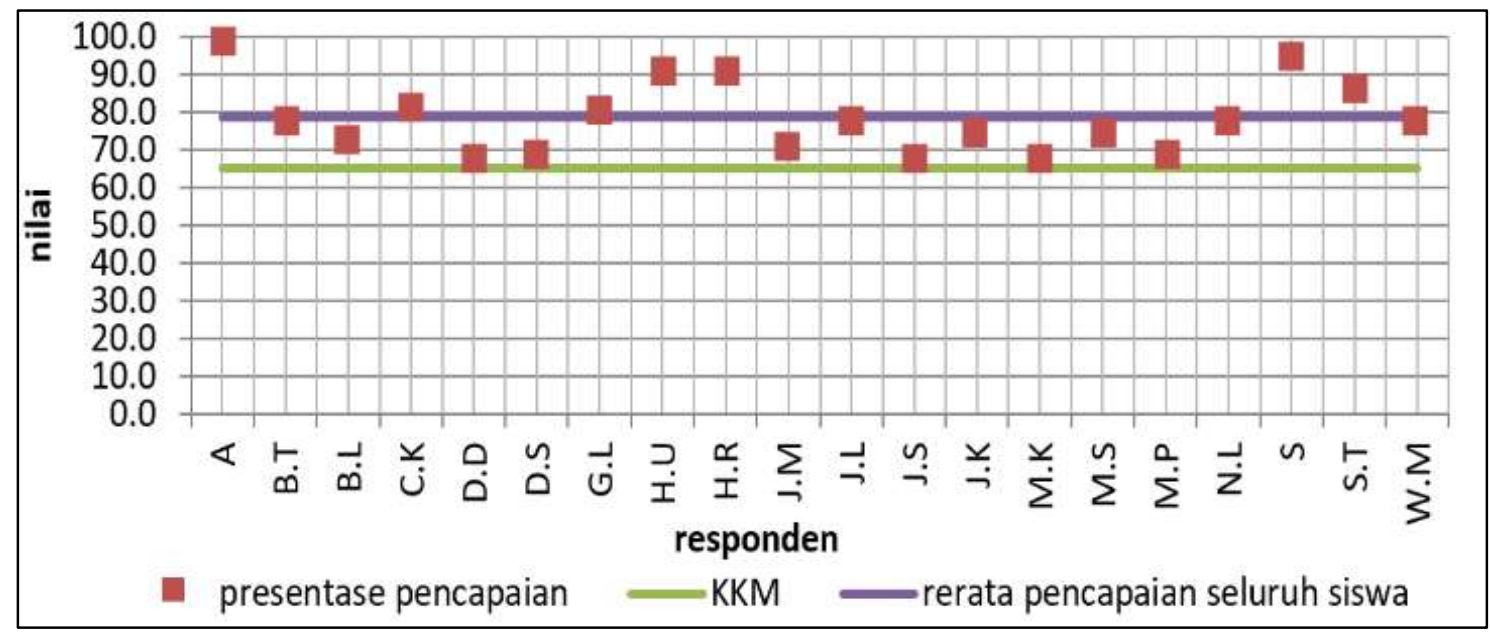

Gambar 5. Tes formatif peserta didik

Hasil belajar peserta didik digunakan untuk mengetahui tingkat penguasaan peserta didik terhadap materi yang diajarkan dan diukur dengan menilai ketuntasan belajar peserta didik. Pada tabel 6 terlihat bahwa seluruh peserta didik (100\%) secara individual maupun klasikal telah berhasil walaupun dengan kualifikasi yang berbeda-beda. Hal ini disebabkan karena peserta didik telah menerima sejumlah pengalaman belajar, sehingga peserta didik mengkonstruksi informasi tentang materi usaha dan energi ke dalam skema pengetahuannya. Semua peserta didik mampu mengerjakan soal yang diberikan oleh guru 
karena model problem posing ini memberikan peluang bagi para peserta didik untuk dapat menyelesaikan masalah-masalah yang mereka hadapi selama proses pembelajaran secara kritis logis dan analitis.

Pencapaian nilai akhir menggambarkan tingkat pencapaian hasil belajar peserta didik pada konsep energi dengan menerapkan model problem posing dan nilai akhir merupakan kontribusi dari pencapaian penilaian kognitif, afektif dan psikomotor serta pencapaian pada tes formatif yang dikualifikasikan pada Tabel 7.

Tabel 7. Kualifikasi persentase pencapaian nilai akhir peserta didik

\begin{tabular}{|c|c|c|c|}
\hline Interval & Frekuensi & Persentase Pencapaian (\%) & Kualifikasi \\
\hline $85-100$ & 6 & 30 & Sangat baik \\
\hline $75-84$ & 14 & 70 & Baik \\
\hline $65-74$ & - & - & Cukup \\
\hline$<65$ & & & Gagal \\
\hline
\end{tabular}

Tabel 7 mendeskripsikan bahwa semua peserta didik yang mengikuti proses pembelajaran dengan menerapkan model problem posing diperoleh sebanyak 6 (30\%) peserta didik memperoleh nilai akhir dengan menempati kualifikasi sangat baik, dan 14 (70\%) peserta didik memperoleh nilai akhir dengan menempati kualifikasi baik, tidak ada peserta didik yang menempati kualifikasi gagal. Jika dibandingkan antara KKM dengan rata-rata skor pencapaian nilai akhir peserta didik maka dapat dikatakan pencapaian kemampuan peserta didik berada pada kategori baik dengan rata-rata nilai pencapaian adalah 83,3 .

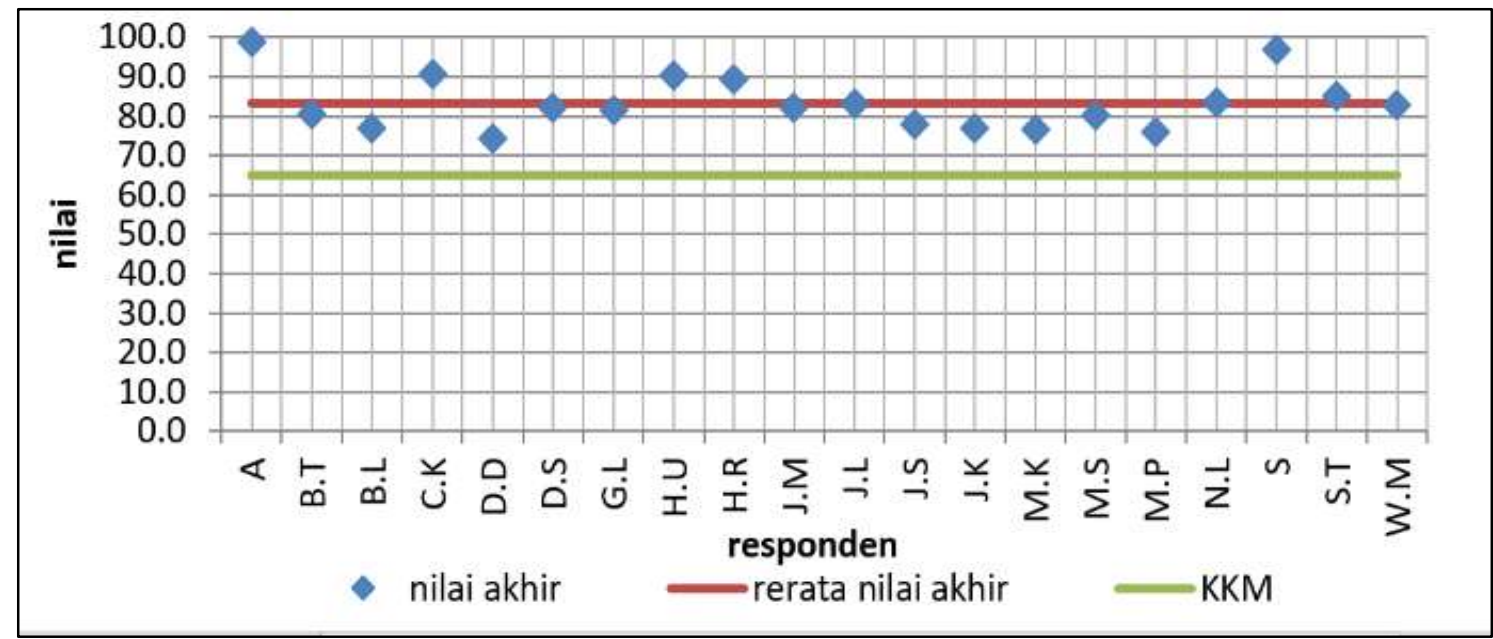

Gambar 6. Nilai akhir peserta didik

Nilai akhir digunakan untuk mengetahui hasil belajar peserta didik pada materi usaha dan energi yang diajarkan. Persentase nilai akhir yang diperoleh pada Gambar 6 menunjukan bahwa tingkat penguasaan individu maupun klasikal dinyatakan tuntas. Hal ini disebabkan karena peserta didik telah memiliki skema pengetahuan yang jelas tentang materi usaha dan energi. Skema inilah yang menyebabkan peserta didik dengan mudah menghubungkan informasi yang telah dipunyainya dengan fenomena baru yang relevan dan merupakan penunjang penguasaan materi tersebut. Selain itu persentase pencapaian nilai akhir ini disebabkan karena keterlibatan peserta didik dalam penilaian proses baik 
kognitif, afektif, maupun psikomotor dan hasil tes akhir (tes formatif) sebagai refleksi atas skema pengetahuan peserta didik yang jelas dan terstruktur dengan baik dan lengkap. Masing-masing nilai yang diperoleh baik nilai proses maupun nilai tes formatif saling mempengaruhi. Nilai akhir dari setiap peserta didik menunjukkan keberhasilan menerapkan model problem posing dalam membantu peserta didik menguasai indikatorindikator pembelajaran.

Dengan demikian dapat dikatakan bahwa pembelajaran dengan menerapkan model problem posing sangat berperan penting dalam proses belajar mengajar karena dapat maningkatkan hasil belajar peserta didik, dimana hasil yang diperoleh dikategorikan baik. Hasil analisis membuktikan bahwa 20 orang peserta didik telah tuntas belajarnya dan dapat dikatakan secara keseluruhan (100\%) peserta didik yang mengikuti KBM telah tuntas belajarnya.

\section{SIMPULAN DAN SARAN}

Berdasarkan hasil penelitian dan pembahasan, maka dapat disimpulkan bahwa setelah penerapan model problem posing dapat diperoleh ketuntasan hasil belajar peserta didik dan membantu peserta didik berperan aktif dan berinteraksi selama pembelajaran. Setelah proses pembelajaran berlangsung, peserta didik mampu menguasai indikator-indikator kompetensi. Ini terbukti pada tes akhir (tes formatif) dimana 20 orang peserta didik (100\%) secara individual maupun klasikal berhasil, walaupun dengan kualifikasi yang berbedabeda dan hasil yang berbeda pula. Rata-rata persentase pencapaian pada tes formatif adalah $78,5 \%$. Nilai akhir yang diperoleh setiap peserta didik, menunjukan keberhasilan model problem posing dalam membantu meningkatkan hasil belajar peserta didik. Terbukti ketuntasan belajar individual maupun klasikal tercapai.

Berdasarkan kesimpulan yang telah dikemukakan, dapat diajukan saran untuk guru dan calon guru, dapat menggunakan model problem posing dalam mengajarkan materi usaha dan energi karena terbukti berhasil membantu peserta didik dalam meningkatkan hasil belajar peserta didik. Kajian dalam penelitian ini merupakan langkah awal dan dapat dilanjutkan dalam suatu penelitian yang lebih mendalam demi peningkatan ilmu pengetahuan dan teknologi di masa mendatang.

\section{DAFTAR PUSTAKA}

Akay, H., \& Boz, N. (2010). The Effect of Problem Posing Oriented Analyses-II Course on the Attitudes Toward Mathematics and Mathematics Self-efficacy of Elementary Prospective Mathematics Teachers. Australian Journal of Teacher Education, 35(1), 6.

Arikunto, S. (2012). Dasar-dasar Evaluasi Pendidikan. Jakarta: Bumi aksara

Chang, K. E., Wu, L. J., Weng, S. E., \& Sung, Y. T. (2012). Embedding Game-based problem-solving Phase into Problem-posing System for Mathematics Learning. Computers \& Education, 58(2), 775-786.

Cankoy, O., \& Darbaz, S. (2010). Effect of a Problem Posing based Problem Solving Instruction on Understanding Problem. Hacettepe University Journal of Education, $38,11-24$.

Hatmawati, R. S., Rokhmat, J., \& Kosim. (2016). Penerapan Model Pembelajaran Problem Posing dengan Metode Eksperimen untuk Meningkatkan Hasil Belajar Fisika pada Peserta didik Kelas VIII SMP Negeri 19 Mataram Tahun Pelajaran 2015/2016. Jurnal Pendidikan Fisika dan Teknologi, 2(1), 23-29. 
Nurliawaty, L., Yusuf, I., \& Widyaningsih, S. W. (2017). Lembar Kerja Peserta Didik (LKPD) Berbasis Problem Solving Polya. Jurnal Pendidikan Indonesia, 6(1), 72-81. Rahmad. M, Norhamidah, D., \& Fakhruddin. (2009). Hasil Belajar Fisika Peserta didik Melalui Penerapan Model Pembelajaran Problem Posing di Kelas X4 Man 1 Pekanbaru. Jurnal Geliga Sains, 3(2), 34-41.

Ratumanan, G. T. (2002). Belajar dan Pembelajaran. Surabaya: University Press.

Riduwan. (2011). Skala Pengukuran Variabel-Variabel Penelitian. Bandung: Alfabeta.

Sadirman, A. (2001). Interaksi dan Motivasi Belajar Mengajar. Jakarta: PT Raja Grafindo Persada.

Sari, R. R. I., Zainuddin, \& Abdul, M. S. (2017). Meningkatkan Hasil Belajar Peserta Didik Melalui Metode Problem Posing dalam Setting Cooperative Learning pada Pembelajaran Fisika di Kelas X 2 SMA Negeri 10 Banjarmasin. Jurnal Ilmiah Pendidikan Fisika, 1(2), 104-112.

Suliyati, Mujasam, Yusuf, I., \& Widyaningsih, S. W. (2018). Penerapan Model PBL Menggunakan Alat Peraga Sederhana Terhadap Hasil Belajar Peserta Didik. Curricula: Journal of Teaching and Learning, 3(1), 11-22.

Trianto. (2007). Model-model Pembelajaran Inovatif Berorientasi Konstruktivistik. Prestasi, Jakarta: Kencana Prenada Media Group.

Irawati, R. K. (2014). Pengaruh Model Problem Solving dan Problem Posing serta Kemampuan Awal terhadap Hasil Belajar Siswa. Jurnal Pendidikan Sains, 2(4), 184-192.

Wakhidah, N. (2007). Ilmu Alamiah Dasar. Prestasi Pustaka, Malang.

Wenno. I. H. (2011). Metodologi Pembelajaran Sains Berbasis Konteks. Yogyakarta; Grafika Indah.

Zakaria, E., \& Ngah, N. (2011). A Preliminary Analysis of Students' Problem-posing Ability and its Relationship to Attitudes Towards Problem Solving. Research Journal of Applied Sciences, Engineering and Technology, 3(9), 866-870. 